\title{
Taxonomic characterization of nine strains isolated from clinical and environmental specimens, and proposal of Corynebacterium tuberculostearicum sp. nov.
}

\author{
Correspondence \\ Catherine Dauga \\ cdauga@pasteur.fr
}

\author{
Carole Feurer, ${ }^{1,2,4}$ † Dominique Clermont, ${ }^{1}$ François Bimet, ${ }^{1}$ \\ Adina Candréa, ${ }^{1}$ Mary Jackson, ${ }^{3}$ Philippe Glaser, ${ }^{2}$ Chantal Bizet ${ }^{1}$ \\ and Catherine Dauga ${ }^{1} \ddagger$
}
1,2,3 Collection de l'Institut Pasteur ${ }^{1}$, Laboratoire de Génomique des Micro-organismes Pathogènes, Département Structure et Dynamique des Génomes ${ }^{2}$ and Unité de Génétique Mycobactérienne, Département Pathogénèse Microbienne ${ }^{3}$, Institut Pasteur, 25-28 rue du Dr Roux, 75724 Paris cedex 15, France
${ }^{4}$ Molecular Diagnostics Unit, Department of Biological Sciences, Cork Institute of Technology, Rossa Avenue, Cork, Ireland

\section{INTRODUCTION}

Corynebacterium species have been detected in various habitats, including dairy products, soil and vegetables (Brennan et al., 2001; Fudou et al., 2002), and in a large variety of hosts such as tortoises, cats (Collins et al., 2001b), dogs (Collins et al., 1999b), seals (Pascual et al., 1998), goats, cows (Fernandez-Garayzabal et al., 1997) and sheep (Collins et al., 2001a). Several species have been implicated in human disease. Corynebacterium diphtheriae is the aetiological agent of diphtheria. Other species are recognized as opportunistic pathogens, and have been isolated from diverse clinical specimens, including the genito-urinary tract (Collins et al., 1999a; Funke et al., 1995; Furness et al., 1979), the respiratory tract (Riegel et al., 1995b, 1997b; Zimmermann et al., 1998), blood samples (Riegel et al., 1997a; Funke et al., 1997c) and surgical infections (Esteban et al., 1999; Yassin et al., 2002b). In the

†Present address: UMR de Génie et Microbiologie des Procédés Alimentaires, INRA, 78850 Thiverval-Grignon, France.

‡Present address: Plate-forme 4, Génopole, Institut Pasteur, 25-28 rue du Dr Roux, 75724 Paris cedex 15, France.

The GenBank/EMBL/DDBJ accession numbers for the 16S rRNA gene sequences determined in this study are shown in Fig. 2.
2 years before this paper was written, nine novel species had been described, namely Corynebacterium capitovis (Collins et al., 2001a), Corynebacterium testudinoris and Corynebacterium felinum (Collins et al., 2001b), Corynebacterium freneyi (Renaud et al., 2001), Corynebacterium aurimucosum (Yassin et al., 2002a), Corynebacterium mooreparkense (Brennan et al., 2001), Corynebacterium appendicis (Yassin et al., 2002b), Corynebacterium efficiens (Fudou et al., 2002) and Corynebacterium spheniscorum (Goyache et al., 2003).

Some species of the genus Corynebacterium belong to the normal flora of the skin (Funke et al., 1997a; Collins et al., 1988), while others were isolated from specific cutaneous lesions. In leprosy, Corynebacterium spp., referred to as leprosy-derived corynebacteria (LDC) (Beaman et al., 1974), were initially reported as a homogeneous and unique group of organisms within the genus Corynebacterium, and were later included in the 'corynebacteria pathogenic for humans' (Danhaive et al., 1982). A novel species, 'Corynebacterium tuberculostearicum', was described as a lipid-requiring LDC, differing from other corynebacteria by the production of tuberculostearic (10-methyloctadecanoic) acid (Brown et al., 1984), although this name was never validly published. Since this description, other 
members of the genus Corynebacterium have been shown to produce tuberculostearic acid (Funke et al., 1998; Yassin et al., 2002a, b).

Identification of lipophilic corynebacteria appears to be problematic with respect to classic bacteriological methods (Riegel et al., 1995a; Watts et al., 2000). The US Centers for Disease Control and Prevention (CDC) separated lipophilic corynebacteria into groups ANF-1, G-1 and G-2 in addition to groups JK (Corynebacterium jeikeium) and D-2 (Corynebacterium urealyticum) using biochemical tests (Hollis \& Weaver, 1981; Riegel et al., 1992, 1993). According to their ability to ferment fructose, bacteria isolated from urethritis samples were separated into 'Corynebacterium genitalium' pathogenic biotypes and 'Corynebacterium pseudogenitalium' saprophytic biotypes (Furness et al., 1979). In disagreement with these data, DNA-DNA hybridizations distinguished five genomic groups of lipidrequiring corynebacteria (Riegel et al., 1995a). Genomospecies I included 'C. tuberculostearicum' LDC8, strain CDC G 5840 (G-2 group), strain CDC F 8156 (G-1 group) and three different ' $C$. pseudogenitalium' biotypes. Numerous descriptions of novel lipophilic species of the genus Corynebacterium required the use of molecular-based approaches (Riegel et al., 1995a; Neubauer et al., 1991; Funke et al., 1997b; Fernandez-Garayzabal et al., 1997; Yassin et al., 2002b). The implementation of 16S rRNA gene sequencing combined with improved phenotypic approaches (in particular, biochemical characterization using bioMérieux API $50 \mathrm{CH}$, API ZYM or API Coryne) has provided an accurate system for the identification of novel corynebacteria. Recently, this strategy has led to the incrimination of 'C. tuberculostearicum' as a causative agent in mastitis (Paviour et al., 2002).

During the course of the characterization of strains deposited in the Collection of the Institut Pasteur (CIP), we identified nine isolates from various clinical and food samples as lipophilic Corynebacterium spp. On the basis of phylogenetic investigations, it is suggested that they be classified as 'C. tuberculostearicum'. Phenotypic comparison of the nine isolates, 'C. tuberculostearicum' strains CIP $107291^{\mathrm{T}}$ and CIP 107067 and 'C. pseudogenitalium' CIP 106714 led us to an emended description of ' $C$. tuberculostearicum' and the formal proposal of Corynebacterium tuberculostearicum sp. nov.

\section{METHODS}

Bacterial strains and culture conditions. The nine unidentified strains were isolated from different sources (Table 1). 'C. tuberculostearicum' strain CIP $107291^{\mathrm{T}}\left(=\mathrm{CCUG} 45418^{\mathrm{T}}=\right.$ ATCC $\left.35529^{\mathrm{T}}\right)$, also named Medalle $\mathrm{X}^{\mathrm{T}}$ or LDC-20 $0^{\mathrm{T}}$ (Brown et al., 1984; Danhaive et al., 1982), and 'C. tuberculostearicum' strain CIP 107067 (=CCUG 41662) were originally obtained from the Culture Collection of the University of Göteborg. 'C. pseudogenitalium' (C-1 type) strain CIP 106714 (=CECT $763=$ ATCC 33035) (Furness et al., 1979) was obtained from the Spanish Type Culture Collection (CECT). The 12 strains were grown on trypto casein soy agar (Bio-Rad) supplemented with $1 \%$ (v/v) Tween 80 (Riegel et al., 1995a; Watts et al., 2000).

Biochemical characterization. Four commercially available galleries, API Coryne, API ZYM, Api $50 \mathrm{CH}$ and Biotype-100 strips, were used according to the instructions of the manufacturer (bioMérieux) to determine biochemical characteristics, i.e. fermentation profiles, enzymic reactions and assimilation tests. They were inoculated with a bacterial suspension enriched with $1 \%(\mathrm{v} / \mathrm{v})$ Tween 80 .

PAGE analysis of whole-cell protein. Cellular protein extracts for PAGE analysis were prepared as described previously (Barreau \& Hansen, 2000). Densitometric analysis, normalization and comparison of protein patterns were performed using GelCompar version 2.5 (Applied Maths).

Fatty acid analysis and tuberculostearic acid detection. Fatty acid methyl esters and mycolic acid methyl esters were extracted as described previously (Phetsuksiri et al., 1999). Detection of mycolic acids was performed with TLC (Minnikin et al., 1980). Fatty acid methyl esters were analysed by GC on a Shimadzu GC-14A chromatograph using a methyl silicone $5 \%$ phenyl column operating at a temperature of $175^{\circ} \mathrm{C}$ for 2 min followed by a programmed increase of $8{ }^{\circ} \mathrm{C} \min ^{-1}$ to $300^{\circ} \mathrm{C}$. The eluted peak of tuberculostearic

Table 1. 'C. tuberculostearicum' reference strains and unnamed lipophilic corynebacteria used in this study

\begin{tabular}{|llll|}
\hline Strain & Date & $\begin{array}{c}\text { Country (town) } \\
\text { of origin }\end{array}$ & \multicolumn{1}{c|}{$\begin{array}{c}\text { Clinical or environmental } \\
\text { source (pathology) }\end{array}$} \\
\hline 'C. tuberculostearicum' CIP 107291 & & Philippines & Bone marrow (leprosy) \\
'C. tuberculostearicum' CIP 107067 & 1901 & Sweden & Contaminant, industrial laboratory \\
CIP 101775 & 1999 & France (Lille) & Unguinal node (soft chancre) \\
CIP 102076 & 1985 & France & Tinned tuna \\
CIP 102124 & 1985 & France (Bordeaux) & Lymph node \\
CIP 102211 & 1986 & France (Royan) & Blood \\
CIP 102346 & 1986 & France (Le Rancy) & Urethra \\
CIP 102590 & 1986 & France (Bordeaux) & Skin (no leprosy lesion) \\
CIP 102622 & 1986 & France (Paris) & Peritoneum (peritonitis) \\
CIP 102645 & 1986 & France (Sens) & Urine \\
CIP 102857 & 1986 & France (Paris) & Healthy urogenital tract \\
'C. pseudogenitalium' CIP 106714 & 1987 & Unknown & \\
\hline
\end{tabular}


acid was identified by comparing its retention time with the retention time of the tuberculostearic acid standard of Mycobacterium tuberculosis.

Genomic DNA extraction. Bacteria were scraped from the agar and resuspended in $200 \mu \mathrm{l}$ TE buffer $(10 \mathrm{mM}$ Tris/HCl, $1 \mathrm{mM}$ EDTA, pH 7•4). After the addition of $50 \mu$ lysozyme $\left(5 \mathrm{mg} \mathrm{ml}^{-1}\right.$, $\mathrm{pH} 7)$ and $30 \mu \mathrm{l}$ RNase A from bovine pancreas $\left(10 \mathrm{mg} \mathrm{ml}^{-1}\right)$, the samples were incubated for $30 \mathrm{~min}$ at $37^{\circ} \mathrm{C}$. Each lysate was transferred to a $2 \mathrm{ml}$ tube (Sarstedt) containing $20 \mu \mathrm{l} 10 \%$ SDS, $0 \cdot 2 \mathrm{~g}$ acid-washed glass beads $(212-300 \mu \mathrm{m}$; Sigma) and $200 \mu \mathrm{l} \mathrm{phenol/}$ chloroform/isoamyl alcohol $(25: 24: 1$ by vol.). The tubes were shaken for two periods of $40 \mathrm{~s}$ at a speed of $6 \mathrm{~m} \mathrm{~s}^{-1}$ in a Savant FastPrep apparatus and then centrifuged at 14000 r.p.m. for $20 \mathrm{~min}$. The upper phase containing DNA was precipitated with absolute ethanol at $-20^{\circ} \mathrm{C}$. After centrifugation, the pellets were washed with $70 \%$ ethanol, dried and dissolved in $200 \mu \mathrm{l}$ TE buffer.

165 rRNA gene amplification. $16 \mathrm{~S}$ rRNA genes were amplified by PCR using the universal primers A (5'-AGAGTTTGATCCTGGCTCAG-3', positions 8-27 according to the Escherichia coli numbering system; Brosius et al., 1978) and H (5'-AAGGAGGTGATCCAGCCGCA-3', positions 1541-1522) (Böttger, 1989). Each reaction was performed in a $100 \mu \mathrm{l}$ volume containing $20 \mathrm{pmol}$ each primer, 2.5 U Taq DNA polymerase (Roche Applied Science), $10 \mu \mathrm{l}$ reaction buffer containing $\mathrm{MgCl}_{2}, 0.3 \mathrm{mM}$ each dNTP (Pharmacia Biotech) and $1 \mu \mathrm{l}$ template DNA. PCR amplification was carried out in a GeneAmp thermal cycler (Applied Biosystems), using the following thermal profile: $94^{\circ} \mathrm{C}$ for $4 \mathrm{~min}$, followed by 25 cycles of $94{ }^{\circ} \mathrm{C}$ for $1 \mathrm{~min}, 57^{\circ} \mathrm{C}$ for $1 \mathrm{~min}$ and $72^{\circ} \mathrm{C}$ for $2 \mathrm{~min}$, with a final extension step at $72{ }^{\circ} \mathrm{C}$ for $5 \mathrm{~min}$. PCR products were examined using $1 \%$ $(\mathrm{w} / \mathrm{v})$ agarose gel electrophoresis and ethidium bromide staining. SmartLadder (Eurogentec) was used as a molecular size marker.

16S rRNA gene sequencing. Each PCR product was treated using the ExoSAP-IT exonuclease I and shrimp alkaline phosphatase protocol (USB). PCR products were then sequenced using the Taq DyeDeoxy terminator cycle sequencing kit and an ABI PRISM 3700 DNA sequencer according to the instructions of the manufacturer (PE Applied Biosystems). Primers $\mathrm{A}$ and $\mathrm{H}$ and sequencing primers 5'-CTCCTACGGGAGGCAGCAGT-3' (positions 339-358 according to the E. coli numbering system), 5'-ACTGCTGCCTCCCGTAGGAG-3' (positions 358-339), 5' -CGTGCCAGCAGCCGCGGTAAT-3' (positions 514-534), 5'-GCATGTGGTTTAATTCGA-3' (positions 947-964), 5'-TCGAATTAAACCACATGC-3' (positions 964-947) and $5^{\prime}$-AGGGTTGCGCTCGTTGCGG-3' (positions 1115-1097) were used. The GenBank/EMBL/DDBJ accession numbers for the $16 \mathrm{~S}$ rRNA gene sequences determined in this study are shown in Fig. 2.

Computational analysis. The $16 \mathrm{~S}$ rRNA sequences were compared with known sequences in the GenBank/EMBL/DDBJ databases by using the BLASTN 2.2.4 algorithm (Altschul et al., 1997). Sequences were then aligned using the CLUSTAL V algorithm (Higgins, 1994) with default gap penalties. The initial alignment was further refined by eye, introducing gaps to improve the overall alignment, using the alignment editor of the PAUP* version 4.0 software package (Swofford, 1998). Sequence-distance matrices were established in pairwise comparisons by applying the algorithm of Tamura \& Nei (1993). Phylogenetic trees were constructed by the neighbourjoining method (Saitou \& Nei, 1987) using the PHYLIP version 3.5 software package (Felsenstein, 1993). A maximum-likelihood analysis was performed using the same model and an estimated rate gamma shape of $0 \cdot 7484$ with PAUP ${ }^{*} 4.0$ version (Felsenstein, 1981). Maximum-parsimony trees were obtained using 100 random-addition heuristic search replicates and the tree bisection-reconnection branch-swapping option. Statistical significance was evaluated by bootstrap analysis (Felsenstein, 1985), with 100 iterations of bootstrap samplings.

\section{RESULTS AND DISCUSSION}

\section{Phenotypic characterization of strains}

The nine unidentified strains were non-motile, non-sporeforming, pleomorphic, Gram-positive rods, frequently swollen at one or both ends, and aerobic to facultatively anaerobic. On trypto casein soy agar supplemented with $1 \%(\mathrm{v} / \mathrm{v})$ Tween 80 , colonies were whitish and glistening with entire edges $\left(1 \mathrm{~mm}\right.$ diameter after $24-48 \mathrm{~h}$ at $\left.37^{\circ} \mathrm{C}\right)$. All isolates were oxidase-negative, catalase-positive and urease-negative. Most had enzymic activities similar to those of 'C. tuberculostearicum' CIP $107291^{\mathrm{T}}$, CIP 107067 and ' $C$. pseudogenitalium' CIP 106714 in the API ZYM system. Reactions for esterase (C4) and naphthol-ASBI-phosphohydrolase were positive for all strains. No activity was detected for $\alpha$-galactosidase, $\beta$-galactosidase, $\alpha$-fucosidase, lipase (C14), trypsin or $\alpha$-chymotrypsin. Results for nitrate reductase, esterase lipase (C8), leucine arylamidase and alkaline phosphatase production are shown in Table 2. With API $50 \mathrm{CH}$, acid was produced from galactose, glucose, glycerol, fructose, mannose, ribose and 5-ketogluconate but not from mannitol, glycogen, starch, lactose or xylose. Sucrose and maltose were not fermented by any of the strains, even after 3 days incubation (Table 2). Biotype-100 strips showed that the substrates D-glucose, sucrose, D-ribose, glycerol, Lmalate, 2-ketogluconate, succinate, fumarate, L-aspartate,

Table 2. Differential characteristics of C. tuberculostearicum and its nearest phylogenetic relatives

Species/strains: 1, C. accolens CIP $104783^{\mathrm{T}}$; 2, 'C. fastidiosum' CIP 103808; 3, C. macginleyi CIP $104099^{\mathrm{T}}$; 4, 'C. segmentosum' CIP 107068; 5, C. tuberculostearicum ( $n=11)$; 6, 'C. pseudogenitalium' CIP 106714. Values for C. tuberculostearicum are percentages of strains giving positive results.

\begin{tabular}{|lrrrrrr|}
\hline Characteristic & $\mathbf{1}$ & $\mathbf{2}$ & $\mathbf{3}$ & $\mathbf{4}$ & $\mathbf{5}$ & $\mathbf{6}$ \\
\hline Production of: & & & & & & \\
$\quad$ Nitrate reductase & + & + & + & + & 27 & - \\
Pyrazinamidase & - & - & - & - & 100 & + \\
Alkaline phosphatase & - & + & + & + & 91 & + \\
Leucine arylamidase & + & + & - & - & 91 & + \\
-Glucosidase & + & - & - & + & 0 & - \\
Esterase lipase & + & + & + & + & 91 & + \\
Fermentation of: & & & & & & \\
Sucrose & - & + & + & + & 82 & + \\
Maltose & + & + & - & - & 91 & - \\
Glycerol & + & - & + & - & 100 & + \\
Galactose & - & - & + & - & 100 & + \\
& & & & & & \\
\hline
\end{tabular}


L-glutamate, L-proline and L-serine were always used as sole carbon sources. L-Alanine was assimilated by all strains except 'C. tuberculostearicum' CIP 107067. 2-Ketogluconate was assimilated by all strains except ' $C$. pseudogenitalium' CIP 106714. The API Coryne system generated the numerical code 6100324 for ' $C$. tuberculostearicum' strains CIP $107291^{\mathrm{T}}$ and CIP 102590, 6100325 for strains CIP 102211, CIP 102346, CIP 101775, 'C. tuberculostearicum' CIP 107067 and 'C. pseudogenitalium' CIP 106714, 7100325 for strains CIP 102124, CIP 102857 and CIP 102076, 6100305 for strain CIP 102622 and 2100325 for strain CIP 102645. These codes corresponded to Corynebacterium CDC group G in the API Coryne profile index. GC analyses of nonhydroxylated fatty acid methyl esters showed that $\mathrm{C}_{18: 0}$, $\mathrm{C}_{18: 1 \text { cis } 9}$ and $\mathrm{C}_{18: 2}$ were the predominant cellular fatty acids in the nine strains, 'C. tuberculostearicum' CIP $107291^{\mathrm{T}}$ and CIP 107067, in agreement with a previous study (Bernard et al., 1991). Small amounts of tuberculostearic acid $(0 \cdot 83-4 \cdot 42 \%)$ and mycolic acids were also detected in the strains. All these strains clustered together in SDS-PAGE analysis and formed a distinct branch with a correlation level of more than $72 \%$ (Fig. 1). These chemotaxonomic findings demonstrated that the nine strains, 'C. tuberculostearicum' strains CIP $107291^{\mathrm{T}}$ and CIP 107067 and 'C. pseudogenitalium' CIP 106714 represented a homogeneous group.

\section{Phylogenetic analysis}

To ascertain the phylogenetic positions of the isolates, complete 16S rRNA gene sequences (1512 nucleotides) of the nine unidentified strains, 'C. tuberculostearicum' CIP $107291^{\mathrm{T}}$ and CIP 107067 and 'C. pseudogenitalium' CIP

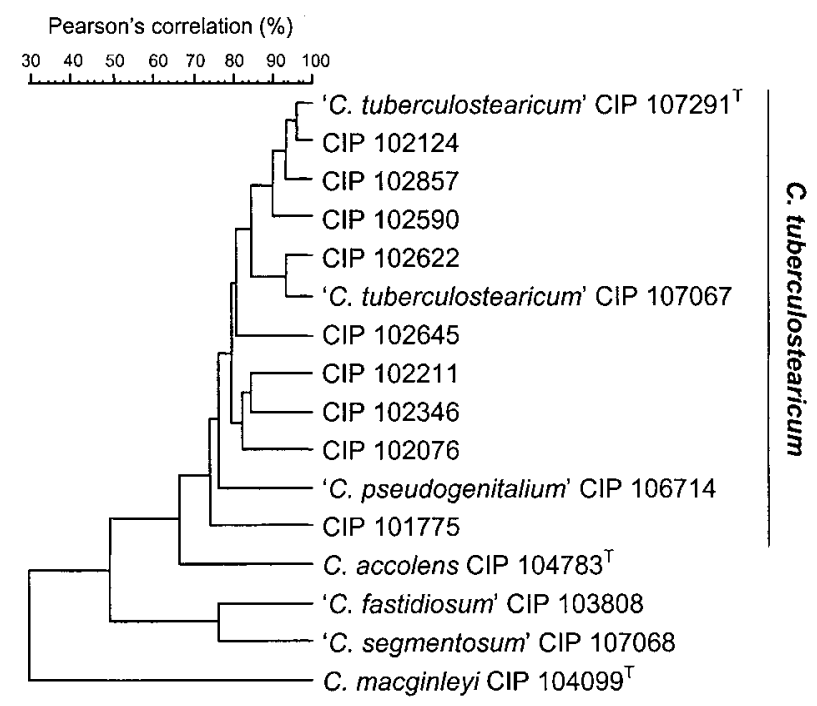

Fig. 1. Similarity dendrogram based on whole-cell protein patterns of the nine unidentified strains, 'C. tuberculostearicum' and related strains. For convenience, levels of correlation are expressed as percentages of similarity.
106714 were determined and subjected to a comparative analysis. Sequence searches of the GenBank/EMBL/DDBJ databases revealed that the nine unidentified strains were closely related to species of the genus Corynebacterium. The $16 \mathrm{~S}$ rRNA gene sequences of the nine strains displayed high levels of similarity $(89 \cdot 8-98 \cdot 9 \%)$ to those of previously described members of the genus Corynebacterium. A preliminary phylogenetic analysis based on Corynebacterium 16S rRNA gene sequences deposited in international databases showed that the nine sequences clustered with 'C. tuberculostearicum' ATCC $35692^{\mathrm{T}}$ (accession no. $\mathrm{X} 84247$ ) and 'C. pseudogenitalium' ATCC 33035 (U87822), confirming that the isolates were members of the genus Corynebacterium (data not shown). A neighbour-joining phylogenetic tree depicting the relationships between the strains and the nearest Corynebacterium species is shown in Fig. 2. The $16 \mathrm{~S}$ rRNA gene sequences of the isolates grouped with those of ' $C$. pseudogenitalium' CIP 106714 and 'C. tuberculostearicum' strains CIP $107291^{\mathrm{T}}$ and CIP 107067. Comparison of sequences from this monophyletic group revealed 0-8 nucleotide differences (corresponding to $100-99 \cdot 2 \%$ similarity). The high levels of 16S rRNA gene sequence similarity suggested that the nine strains, 'C. tuberculostearicum' strains CIP $107291^{\mathrm{T}}$ and CIP 107067 and 'C. pseudogenitalium' CIP 106714 belonged to the same species (Drancourt et al., 2000).

\section{Differential properties}

The monophyletic group of 'C. tuberculostearicum' and related strains formed a distinct lineage within a small

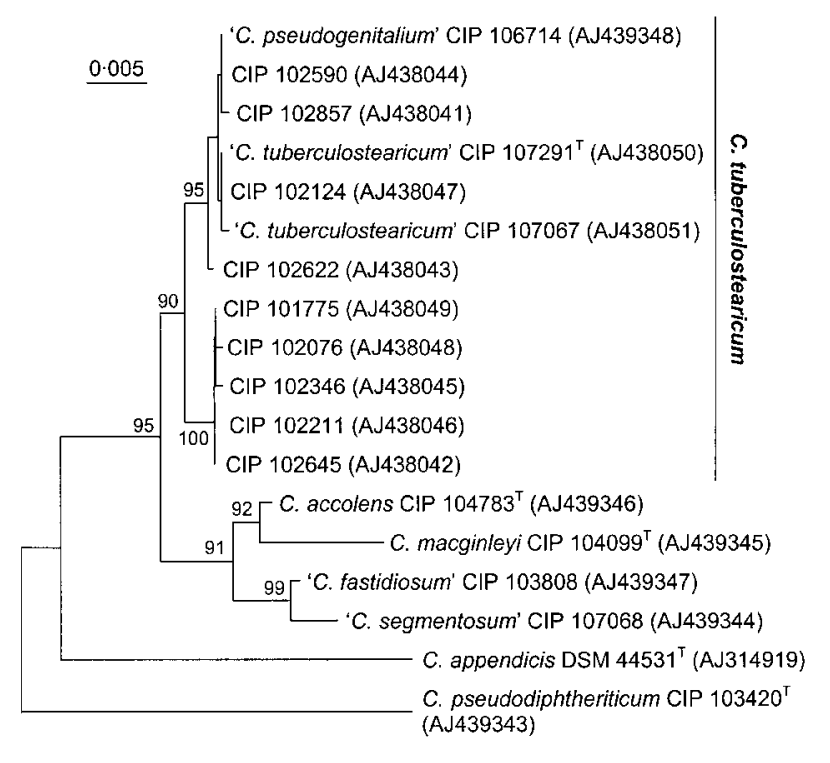

Fig. 2. Neighbour-joining tree based on 16S rRNA gene sequences showing the relationships between the nine unidentified strains and ' $C$. tuberculostearicum' and some other related taxa. Significant bootstrap values (\%) are given at branching points. Bar, 0.005 substitutions per site. 
phylogenetic group including Corynebacterium accolens, Corynebacterium macginleyi, 'Corynebacterium segmentosum' and 'Corynebacterium fastidiosum'. Sequence similarities between 'C. tuberculostearicum' taxa and C. accolens, $C$. macginleyi, 'C. segmentosum' and 'C. fastidiosum' ranged from $97 \cdot 54$ to $98 \cdot 57 \%$. These similarity values, alone, are too high (above $97 \%$ ) to distinguish 'C. tuberculostearicum' formally from closely related species (Stackebrandt \& Goebel, 1994). Previous studies have shown that numerous species of the genus Corynebacterium that exhibited only limited $16 \mathrm{~S}$ rRNA divergence presented sufficient distinctive characters, fully justifying their classification in separate species (Pascual et al., 1995). This was the case for Corynebacterium ulcerans, $C$. diphtheriae and Corynebacterium pseudotuberculosis, which share more than $98 \%$ 16S rRNA similarity. Similarly, Corynebacterium propinquum and Corynebacterium pseudodiphtheriticum share more than 99\% 16S rRNA similarity (Pascual et al., 1995; Ruimy et al., 1995). Thus, the $97 \%$ limit is not decisive for separating species of the genus Corynebacterium: further characteristics are required. Biochemical features such as production of alkaline phosphatase, leucine arylamidase, nitrate reductase, esterase lipase, pyrazinamidase and $\alpha$ glucosidase or fermentation of glycerol and galactose confirmed that the 12 strains were distinct from C. accolens CIP $104783^{\mathrm{T}}$, C. macginleyi CIP $104099^{\mathrm{T}}$, 'C. segmentosum' CIP 107068 and 'C. fastidiosum' CIP 103808 (Table 2). The type strain of $C$. accolens produced acid from maltose, as described previously (Neubauer et al., 1991). However, another study showed that only $7 \%$ of strains of $C$. accolens studied fermented maltose (Riegel et al., 1995a). Thus, the fermentation of maltose becomes an unreliable characteristic, as reported previously (Funke et al., 1997a). We also noted that acid was produced from glycogen by $C$. accolens CIP $104783^{\mathrm{T}}$ with API $50 \mathrm{CH}$ but not with API Coryne, while the 11 strains of ' $C$. tuberculostearicum', C. genitalium CIP 106714, C. macginleyi CIP $104099^{\mathrm{T}}$, 'C. segmentosum' CIP 107068 and 'C. fastidiosum' CIP 103808 did not ferment glycogen with either API $50 \mathrm{CH}$ or API Coryne. SDS-PAGE patterns of C. accolens CIP $104783^{\mathrm{T}}$, C. macginleyi CIP $104099^{\mathrm{T}}$, 'C. segmentosum' CIP 107068 and 'C. fastidiosum' CIP 103808 did not display a close affinity with those of 'C. tuberculostearicum'. In addition, a previous DNA hybridization study showed clearly that $C$. accolens, $C$. macginleyi and 'C. tuberculostearicum' (strain LDC 8) belong to separate genomic species (Riegel et al., 1995a). Recently, a lipophilic species, C. appendicis, isolated from humans, has been described (Yassin et al., 2002b). This novel species can be differentiated from ' $C$. tuberculostearicum' by its ability to hydrolyse urea and by its position in the 16S rRNA phylogenetic tree (Fig. 2).

Consequently, we feel that, on the basis of phenotypic data, whole-cell protein profiles and 16S rRNA sequence analysis, it is reasonable to assign the nine Corynebacterium strains CIP 101775, CIP 102076, CIP 102124, CIP 102211, CIP 102346, CIP 102590, CIP 102622, CIP 102645, CIP 102857 and 'C. pseudogenitalium' CIP 106714 to the species
Corynebacterium tuberculostearicum. An emended description of this species is presented below.

\section{Description of Corynebacterium tuberculostearicum sp. nov.}

Corynebacterium tuberculostearicum (tu.ber.cu.lo.stea'ri. cum. N.L. neut. adj. tuberculostearicum of tuberculostearic acid, which is contained in the cells).

Cells are pleomorphic, Gram-positive rods, non-motile and non-spore-forming, developing coccoid forms in stationary cultures. Colonies on trypto casein soy agar supplemented with Tween 80 are circular, convex, glistening and $1 \mathrm{~mm}$ in diameter. Aerobic to facultatively anaerobic. Lipophilic. Oxidase-negative and catalase-positive. Corynebacterium mycolic acids are present and the fatty acid profiles contain tuberculostearic acid. Acid is produced from galactose, glucose, glycerol, fructose, mannose, ribose and 5-ketogluconate but not from mannitol, glycogen, starch, sorbitol, lactose, inulin or xylose. Production of acid from trehalose, maltose, gluconate, sucrose and $\mathrm{N}$ acetylglucosamine is variable. Urea, aesculin and gelatin are not hydrolysed. Presence of nitrate reductase is variable. DNase is absent. Esterase (C4) and naphthol-AS-BIphosphohydrolase activities are detected. Presence of esterase lipase (C8), leucine arylamidase, valine arylamidase, cystine arylamidase, acid phosphatase and alkaline phosphatase is variable. No activity is detected for $\alpha$ galactosidase, $\beta$-galactosidase, $\alpha$-glucosidase, $\beta$-glucosidase, $\alpha$-fucosidase, lipase (C14), trypsin or $\alpha$-chymotrypsin. The following substrates are utilized in 2 or 4 days: D-glucose, sucrose, D-ribose, glycerol, L-malate, 2-ketogluconate, succinate, fumarate, L-aspartate, L-glutamate, L-proline and L-serine. The following substrates are not utilized in 6 days: caprate, citrate and DL-glycerate.

The type strain, Medalle $\mathrm{X}^{\mathrm{T}}\left(=\mathrm{LDC}-20^{\mathrm{T}}=\mathrm{CIP} 107291^{\mathrm{T}}=\right.$ CCUG $45418^{\mathrm{T}}=$ ATCC $35529^{\mathrm{T}}$ ), was isolated from a case of lepromatous leprosy in the Philippines (Brown et al., 1984). The type strain has all the properties given for the species. In addition, it assimilates D-mannose.

\section{ACKNOWLEDGEMENTS}

We thank E. Falsen (Culture Collection, University of Göteborg, Sweden) for kindly providing strains of C. tuberculostearicum. We are grateful to J. P. Euzéby (Ecole Nationale Vétérinaire de Toulouse, France) for help in coining the species epithet.

\section{REFERENCES}

Altschul, S. F., Madden, T. L., Schäffer, A. A., Zhang, J., Zhang, Z., Miller, W. \& Lipman, D. J. (1997). Gapped BLAST and PSI-BLAST: a new generation of protein database search programs. Nucleic Acids Res 25, 3389-3402.

Barreau, C. \& Hansen, W. (2000). Chimiotaxonomie. In Précis de Bactériologie Clinique, chapter 2, pp. 27-52. Edited by J. Freney, F. Renaud, W. Hansen \& C. Bollet. Paris: ESKA (in French). 
Beaman, B. L., Kim, K.-S., Lanéelle, M. A. \& Barksdale, L. (1974). Chemical characterization of organisms isolated from leprosy patients. J Bacteriol 117, 1320-1329.

Bernard, K. A., Bellefeuille, M. \& Ewan, E. P. (1991). Cellular fatty acid composition as an adjunct to the identification of asporogenous, aerobic gram-positive rods. J Clin Microbiol 29, 83-89.

Böttger, E. C. (1989). Rapid determination of bacterial ribosomal RNA sequences by direct sequencing of enzymatically amplified DNA. FEMS Microbiol Lett 65, 171-176.

Brennan, N. M., Brown, R., Goodfellow, M., Ward, A. C., Beresford, T. P., Simpson, P. J., Fox, P. F. \& Cogan, T. M. (2001). Corynebacterium mooreparkense sp. nov. and Corynebacterium casei sp. nov., isolated from the surface of a smear-ripened cheese. Int J Syst Evol Microbiol 51, 843-852.

Brosius, J., Palmer, M. L., Kennedy, P. J. \& Noller, H. F. (1978). Complete nucleotide sequence of a $16 \mathrm{~S}$ ribosomal RNA gene from Escherichia coli. Proc Natl Acad Sci U S A 75, 4801-4805.

Brown, S., Lanéelle, M. A., Asselineau, J. \& Barksdale, L. (1984). Description of Corynebacterium tuberculostearicum sp. nov., a leprosy-derived Corynebacterium. Ann Microbiol (Paris) 135B, 251-267.

Collins, M. D., Burton, R. A. \& Jones, D. (1988). Corynebacterium amycolatum sp. nov., a new mycolic acid-less Corynebacterium species from human skin. FEMS Microbiol Lett 49, 349-352.

Collins, M. D., Bernard, K. A., Hutson, R. A., Sjödén, B., Nyberg, A. \& Falsen, E. (1999a). Corynebacterium sundsvallense sp. nov., from human clinical specimens. Int J Syst Bacteriol 49, 361-366.

Collins, M. D., Hoyles, L., Lawson, P. A., Falsen, E., Robson, R. L. \& Foster, G. (1999b). Phenotypic and phylogenetic characterization of a new Corynebacterium species from dogs: description of Corynebacterium auriscanis sp. nov. J Clin Microbiol 37, 3443-3447.

Collins, M. D., Hoyles, L., Foster, G., Sjödén, B. \& Falsen, E. (2001a). Corynebacterium capitovis sp. nov., from a sheep. Int J Syst Evol Microbiol 51, 857-860.

Collins, M. D., Hoyles, L., Hutson, R. A., Foster, G. \& Falsen, E. (2001b). Corynebacterium testudinoris sp. nov. from a tortoise, and Corynebacterium felinum sp. nov., from a Scottish wild cat. Int J Syst Evol Microbiol 51, 1349-1352.

Danhaive, P., Hoet, P. \& Cocito, C. (1982). Base compositions and homologies of deoxyribonucleic acids of corynebacteria isolated from human leprosy lesions and of related microorganisms. Int J Syst Bacteriol 32, 70-76.

Drancourt, M., Bollet, C., Carlioz, A., Martelin, R., Gayral, J. P. \& Raoult, D. (2000). 16S ribosomal DNA sequence analysis of a large collection of environmental and clinical unidentifiable bacterial isolates. J Clin Microbiol 38, 3623-3630.

Esteban, J., Nieto, E., Calvo, R., Fernandez-Roblas, R., ValeroGuillen, P. L. \& Soriano, F. (1999). Microbial characterization and clinical significance of Corynebacterium amycolatum strains. Eur J Clin Microbiol Infect Dis 18, 518-521.

Felsenstein, J. (1981). Evolutionary trees from DNA sequences: a maximum likelihood approach. J Mol Evol 17, 368-376.

Felsenstein, J. (1985). Confidence limits on phylogenies: an approach using the bootstrap. Evolution 39, 783-791.

Felsenstein, J. (1993). PHYLIP: phylogenetic inference package, version 3.53c. Distributed by the author. Department of Genetics, University of Washington, Seattle, USA.

Fernandez-Garayzabal, J. F., Collins, M. D., Hutson, R. A., Fernandez, E., Monasterio, R., Marco, J. \& Dominguez, L. (1997). Corynebacterium mastitidis sp. nov., isolated from milk of sheep with subclinical mastitis. Int J Syst Bacteriol 47, 1082-1085.
Fudou, R., Jojima, Y., Seto, A., Yamada, K., Kimura, E., Nakamatsu, T., Hiraishi, A. \& Yamanaka, S. (2002). Corynebacterium efficiens sp. nov., a glutamic-acid-producing species from soil and vegetables. Int J Syst Evol Microbiol 52, 1127-1131.

Funke, G., Bernard, K. A., Bucher, C., Pfyffer, G. E. \& Collins, M. D. (1995). Corynebacterium glucuronolyticum sp. nov. isolated from male patients with genitourinary infections. Med Microbiol Lett 4, 204-215.

Funke, G., von Graevenitz, A., Clarridge, J. E., III \& Bernard, K. A. (1997a). Clinical microbiology of coryneform bacteria. Clin Microbiol Rev 10, 125-159.

Funke, G., Hutson, R. A., Hilleringmann, M., Heizmann, W. R. \& Collins, D. (1997b). Corynebacterium lipophiloflavum sp. nov. isolated from a patient with bacterial vaginosis. FEMS Microbiol Lett 150, 219-224.

Funke, G., Lawson, P. A. \& Collins, M. D. (1997c). Corynebacterium mucifaciens sp. nov., an unusual species from human clinical material. Int J Syst Bacteriol 47, 952-957.

Funke, G., Osorio, C. R., Frei, R., Riegel, P. \& Collins, M. D. (1998). Corynebacterium confusum sp. nov., isolated from human clinical specimens. Int J Syst Bacteriol 48, 1291-1296.

Furness, G., Sambury, S. \& Evangelista, A. T. (1979). Corynebacterium pseudogenitalium sp. nov. Commensals of the human male and female urogenital tracts. Invest Urol 16, 292-295.

Goyache, J., Vela, A. I., Collins, M. D. \& 7 other authors (2003) Corynebacterium spheniscorum sp. nov., isolated from the cloacae of wild penguins. Int J Syst Evol Microbiol 53, 43-46.

Higgins, D. G. (1994). CLUSTAL V: multiple alignment of DNA and protein sequences. Methods Mol Biol 25, 307-318.

Hollis, D. G. \& Weaver, R. E. (1981). Gram-positive Organisms: a Guide to Identification. Atlanta, GA: Special Bacteriology Section, Centers for Disease Control.

Minnikin, D. E., Hutchinson, I. G., Caldicott, A. B. \& Goodfellow, M. (1980). Thin-layer chromatography of methanolysates of mycolic acid-containing bacteria. J Chromatogr 188, 221-223.

Neubauer, M., Sourek, J., Ryc, M., Bohacek, J., Mara, M. \& Mnukova, J. (1991). Corynebacterium accolens sp. nov., a grampositive rod exhibiting satellitism, from clinical material. Syst Appl Microbiol 14, 46-51.

Pascual, C., Lawson, P. A., Farrow, J. A. E., Gimenez, M. N. \& Collins, M. D. (1995). Phylogenetic analysis of the genus Corynebacterium based on 16S rRNA gene sequences. Int J Syst Bacteriol 45, 724-728.

Pascual, C., Foster, G., Alvarez, N. \& Collins, M. D. (1998). Corynebacterium phocae sp. nov., isolated from the common seal (Phoca vitulina). Int J Syst Bacteriol 48, 601-604.

Paviour, S., Musaad, S., Roberts, S., Taylor, G., Taylor, S., Shore, K., Lang, S. \& Holland, D. (2002). Corynebacterium species isolated from patients with mastitis. Clin Infect Dis 35, 1434-1440.

Phetsuksiri, B., Baulard, A. R., Cooper, A., Minnikin, D. E., Douglas, J. D., Besra, G. S. \& Brennan, P. J. (1999). Antimycobacterial activities of isoxyl and new derivatives through the inhibition of mycolic acid synthesis. Antimicrob Agents Chemother 43, 1042-1051.

Renaud, F. N. R., Aubel, D., Riegel, P., Meugnier, H. \& Bollet, C. (2001). Corynebacterium freneyi sp. nov., $\alpha$-glucosidase-positive strains related to Corynebacterium xerosis. Int J Syst Evol Microbiol 51, 1723-1728

Riegel, P., Grimont, P. A. D., De Briel, D., Ageron, E., Jehl, F., Pelegrin, M., Monteil, H. \& Monck, R. (1992). Corynebacterium group D2 ('Corynebacterium urealyticum') constitutes a new genomic species. Res Microbiol 143, 307-313. 
Riegel, P., De Briel, D., Prevost, G., Jehl, F., Monteil, H. \& Minck, R. (1993). Taxonomic study of Corynebacterium group ANF-1 strains: proposal of Corynebacterium afermentans sp. nov. containing the subspecies $C$. afermentans subsp. afermentans subsp. nov. and $C$. afermentans subsp. lipophilum subsp. nov. Int J Syst Bacteriol 43, 287-292.

Riegel, P., Ruimy, R., De Briel, D., Prévost, G., Jehl, F., Christen, R. \& Monteil, H. (1995a). Genomic diversity and phylogenetic relationships among lipid-requiring diphtheroids from humans and characterization of Corynebacterium macginleyi sp. nov. Int J Syst Bacteriol 45, 128-133.

Riegel, P., Ruimy, R., De Briel, D., Prevost, G., Jehl, F., Bimet, F., Christen, R. \& Monteil, H. (1995b). Corynebacterium argentoratense sp. nov., from the human throat. Int J Syst Bacteriol 45, 533-537.

Riegel, P., Ruimy, R., Renaud, F. N. R., Freney, J., Prevost, G., Jehl, F., Christen, R. \& Monteil, H. (1997a). Corynebacterium singulare sp. nov., a new species for urease-positive strains related to Corynebacterium minutissimum. Int J Syst Bacteriol 47, 1092-1096.

Riegel, P., Heller, R., Prevost, G., Jehl, F. \& Monteil, H. (1997b). Corynebacterium durum sp. nov., from human clinical specimens. Int J Syst Bacteriol 47, 1107-1111.

Ruimy, R., Riegel, P., Boiron, P., Monteil, H. \& Christen, R. (1995). Phylogeny of the genus Corynebacterium deduced from analyses of small-subunit ribosomal DNA sequences. Int J Syst Bacteriol 45, 740-746.
Saitou, N. \& Nei, M. (1987). The neighbor-joining method: a new method for reconstructing phylogenetic trees. Mol Biol Evol 4, 406-425.

Stackebrandt, E. \& Goebel, B. M. (1994). Taxonomic note: a place for DNA-DNA reassociation and 16S rRNA sequence analysis in the present species definition in bacteriology. Int J Syst Bacteriol 44, 846-849.

Swofford, D. L. (1998). PAUP*. Phylogenetic analysis using parsimony (*and other methods), version 4. Sunderland, MA: Sinauer.

Tamura, K. \& Nei, M. (1993). Estimation of the number of nucleotide substitutions in the control region of mitochondrial DNA in humans and chimpanzees. Mol Biol Evol 10, 512-526.

Watts, J. L., Lowery, D. E., Teel, J. F. \& Rossbach, S. (2000). Identification of Corynebacterium bovis and other coryneforms isolated from bovine mammary glands. J Dairy Sci 83, 2373-2379.

Yassin, A. F., Steiner, U. \& Ludwig, W. (2002a). Corynebacterium aurimucosum sp. nov. and emended description of Corynebacterium minutissimum Collins and Jones (1983). Int J Syst Evol Microbiol 52, 1001-1005.

Yassin, A. F., Steiner, U. \& Ludwig, W. (2002b). Corynebacterium appendicis sp. nov. Int J Syst Evol Microbiol 52, 1165-1169.

Zimmermann, O., Spröer, C., Kroppenstedt, R. M., Fuchs, E., Köchel, H. G. \& Funke, G. (1998). Corynebacterium thomssenii sp. nov., a Corynebacterium with $N$-acetyl- $\beta$-glucosaminidase activity from human clinical specimens. Int J Syst Bacteriol 48, 489-494. 